\title{
The Multiple Vitamin Status of Chinese Pregnant Women with Anemia and Nonanemia in the Last Trimester
}

\author{
Ai-Guo MA ${ }^{1}$, Xue-Cun $\mathrm{CHEN}^{2}$, Yu WANG ${ }^{3}$, Rong-Xian Xu ${ }^{4}$, \\ Ming-Ci ZHENG ${ }^{5}$ and Jue-Sheng $\mathrm{LI}^{1}$ \\ ${ }^{1}$ Institute of Human Nutrition, Medical College of Qingdao University, \\ 38* Dengzhou Road, 266021, Qingdao, China \\ ${ }^{2}$ Institute of Nutrition and Food Hygiene, Chinese Academy of Preventive Medicine, Beijing, China \\ ${ }^{3}$ Lanzhou Medical College, Lanzhou, China \\ ${ }^{4}$ Fujian Medical University, Fuzhou, China \\ ${ }^{5}$ Guilin Medical College, Guilin, China
}

(Received August 4, 2003)

\begin{abstract}
Summary Iron-deficiency or anemia in pregnancy is a major public health problem in China. This cross-sectional study was carried out to observe the association between iron status and multiple vitamin levels of Chinese pregnant women in the third trimester. We measured iron, ascorbic acid, retinol, folate and vitamin $\mathrm{B}_{12}$ in serum, and riboflavin in urine specimens of 1,163 pregnant women in four sites throughout rural and city areas in China. Based on hemoglobin concentrations $(\mathrm{Hb})$, the subjects were divided into an anemia group with $\mathrm{Hb}<110 \mathrm{~g} / \mathrm{L}$ or $\mathrm{Hb} \leq 100 \mathrm{~g} / \mathrm{L}$ as severe anemia group, and nonanemia group with $\mathrm{Hb} \geq 110 \mathrm{~g} / \mathrm{L}$. Results showed that $41.58 \%$ of the population with serum iron $<700 \mu \mathrm{g} / \mathrm{L}$ and $51.04 \%$ of the population with ferritin $<12 \mu \mathrm{g} / \mathrm{L}$ in the anemia group, percentages that were much higher than those in the nonanemia group. Relationships between five vitamins and hemoglobin concentrations of all subjects were observed. There was a lower level of serum ascorbic acid $(291.05 \mu \mathrm{g} / \mathrm{dL})$ in the $\mathrm{Hb} \leq 100 \mathrm{~g} / \mathrm{L}$ group than in the $\mathrm{Hb}$ $\geq 120 \mathrm{~g} / \mathrm{L}$ group $(487.79 \mu \mathrm{g} / \mathrm{dL})(p<0.001)$. Serum levels of vitamin $B_{12}$ and folate were $445.67 \mathrm{pg} / \mathrm{mL}$ and $5.94 \mathrm{ng} / \mathrm{mL}$ in the $\mathrm{Hb} \leq 100 \mathrm{~g} / \mathrm{L}$ group, whose levels were much lower than the levels of $502.01 \mathrm{pg} / \mathrm{mL}(p<0.012)$ and $8.07 \mathrm{ng} / \mathrm{mL}(p<0.010)$ respectively in the $\mathrm{Hb} \geq 120 \mathrm{~g} / \mathrm{L}$ group. Further, cross-sectional analysis showed positive correlations between abnormal hematological results and prevalences of vitamin deficiencies. The subjects with iron-deficiency anemia had much higher rates of vitamin $\mathrm{C}$, folate and vitamin $\mathrm{B}_{12}$ deficiencies than those in the nonanemic subjects, and especially in the deficient rates of ascorbic acid and folate in the anemia $(\mathrm{Hb}<110 \mathrm{~g} / \mathrm{L})$ group, which reached $64.04 \%$ and $22.70 \%$ respectively. Moreover, we observed that the decreasing trends of hemoglobin concentrations were accompanied by the decreases of serum levels of vitamin A, ascorbic acid, folate and vitamin $\mathrm{B}_{12}$. In conclusion, multiple vitamin deficiencies, especially ascorbic acid, retinol and folic acid, may be associated with anemia or iron deficiency in pregnant women in the last trimester. The study suggested that anemic pregnant women in China should be supplemented with iron and multiple vitamins simultaneously.
\end{abstract}

Key Words anemia, pregnancy, iron, multiple vitamin, China

The World Health Organization estimates that 58\% of pregnant women in developing countries are anemic (1). Anemia is still a nutritional problem for pregnant women in China. Many studies showed that the incidence of iron-deficiency anemia was $42 \%$ among pregnant women in the third trimester in the Xi' an area (2) and $55 \%$ of pregnant women with anemia were found in Jilin' city of North China in 1997 (3). It is estimated that the prevalence of anemia may still remain high in Chinese pregnant women, especially in rural areas.

Anemia has many possible causes during pregnancy. It has not only been attributed to increased iron

E-mail: maiguo@public.qd.sd.cn

Supported by a grant from the Nestlé Foundation. requirements, but also associated with deficiencies of micronutrients, especially iron and vitamin C (4). Deficiency of iron in the diet is regarded as the most important factor by far in the etiology of nutritional anemia. Several studies in humans and animals have shown that abnormality of iron metabolism is associated with other relative nutrients. The relationship between vitamin A and anemia among Chinese pregnant women has been analyzed. The serum levels of vitamin A, serum iron, ferritin and transferrin in 40 anemic pregnant women supplemented with the vitamin A for $3 \mathrm{mo}$ were much higher than those in the placebo group (5). A low intake of ascorbic acid was considered to be a factor in accelerating anemia or iron deficiency (6). Supplementation with vitamin $\mathrm{C}$ and retinol may increase 
iron status as measured by hematological indices (7). The low intakes of iron and vitamin $\mathrm{B}_{2}$ were found in Chinese pregnant women in the second and third trimester, which only accounted for $79.6 \%$ and $77.2 \%$ of Chinese RNI (recommended nutrition intake) (8). The prevalence of riboflavin deficiency was $36 \%$ in anemic pregnant women, which was higher than that in the nonanemic group (9).

However, the limited data above were involved in the relationship between iron status and serum multiple vitamin levels. Some of the studies were carried out in small sample sizes, and mainly based on the investigation of iron and single vitamin intake. The objective of this study was to investigate the multiple vitamin status of pregnant women with anemia or iron deficiency and non-anemia by measuring biochemical indices in the populations of China.

\section{SUBJECTS AND METHODS}

Subjects. The study was carried out in November 1999 and April 2000 and involved the examination of 1,163 clinically normal pregnant women aged 20-35 y in the third trimester of pregnancy. The subjects were selected in 4 centers, two rural areas and two developing cities in China. They might geographically differ in variable diets, food supply, living habits and climate and socioeconomic status between different locales. The stages of gestation and estimated date of delivery were calculated from the first day of their last period of menstruation and compared with results of the obstetric examination. All subjects enrolled were healthy pregnant women with no abnormal bleeding and refrained from iron supplementation, smoking and drinking alcohol.

The research was carried out following the ethical standards of the local authorities and informed consent was obtained from every subject.

Blood collection and analysis of iron and vitamins. Specimens of about $5 \mathrm{~mL}$ venous blood and $10 \mathrm{~mL}$ urine from each subject were taken on the same day as the antenatal examination, and stored on ice for transport to the laboratory. Hemoglobin concentration was measured and serum was separated from blood by centrifugation at $2,000 \times g$ for $15 \mathrm{~min}$ at room temperature on arrival in each center. Serum samples were separately stored at $-80^{\circ} \mathrm{C}$ in the dark and then transported to one center by plane for analysis of serum iron (SI), serum ferritin (SF), serum vitamin A, ascorbic acid, riboflavin, vitamin $\mathrm{B}_{12}$ and folate.

Blood hemoglobin concentration was analyzed by using a semi-automatic biochem-analyser (Sysmex F820, China). A standard hemoglobincyanide solution was used in four centers as the quality control of hemoglobin measurements. Measurements of serum ferritin were performed by radioimmnoassay (10), as described by the manufacturer (The North Biol. Tec. Institute, Beijing, China). The criteria for a diagnosis of anemia was $\mathrm{Hb}<110 \mathrm{~g} / \mathrm{L} . \mathrm{SF}<12 \mu \mathrm{g} / \mathrm{L}$ and $\mathrm{SI}<500 \mu \mathrm{g} / \mathrm{L}$, which can be considered abnormal.

Vitamin A in serum was determined by the fluorescent spectrometry method (RF-540, Japan) (11) and ascorbic acid in serum by the 2, 4-dinitrophenylhydrazine method $(12,13)$, and deficient ranges were vita$\min \mathrm{A}<20 \mu \mathrm{g} / \mathrm{dL}(0.70 \mu \mathrm{mol} / \mathrm{L})$ and ascorbic acid $<400 \mu \mathrm{g} / \mathrm{dL}$ respectively; serum level of riboflavin was determined by a ratio of riboflavin/creatine $(\mathrm{Cr})$ and marginal deficiency of riboflavin/ $\mathrm{Cr}$ was $<80 \mu \mathrm{g} / \mathrm{g}$ in urine (14). Folic acid and vitamin $\mathrm{B}_{12}$ in serum were measured by radioimmunoassay method (Diagnostic Products Corporation DPC, USA) and the deficiency of folic acid and vitamin $\mathrm{B}_{12}$ were $<3.0 \mathrm{ng} / \mathrm{mL}$ and $<200 \mathrm{pg} / \mathrm{mL}$ (15).

Statistical analysis. The significance of differences was determined by Independent Samples $t$-test and by the Chi-square $\left(\chi^{2}\right)$ test. The SPSS (10) of statistical software was used.

\section{RESULTS}

Levels of the five vitamins in serum and urine were measured and compared between the two groups of $\mathrm{Hb}$

Table 1. Serum vitamin levels of the three groups divided according to the Hb values of pregnant Chinese women in the last trimester.

\begin{tabular}{|c|c|c|c|c|}
\hline \multirow{2}{*}{ Indices } & \multicolumn{4}{|c|}{ Hemoglobin concentration $(\mathrm{Hb})$ of the groups } \\
\hline & $\leq 100 \mathrm{~g} / \mathrm{L}$ & $101-119 \mathrm{~g} / \mathrm{L}$ & $\geq 120 \mathrm{~g} / \mathrm{L}$ & $p^{\mathrm{c}}$ \\
\hline$\underset{(n)^{\mathrm{b}}}{\operatorname{Retinol}(\mu \mathrm{g} / \mathrm{dL})}$ & $\begin{array}{l}51.9 \pm 17.4^{\mathrm{a}} \\
\quad(328)\end{array}$ & $\begin{array}{c}62.3 \pm 16.1 \\
(393)\end{array}$ & $\begin{array}{c}64.1 \pm 14.8 \\
(379)\end{array}$ & $<0.001$ \\
\hline $\begin{array}{l}\text { Vitamin } C(\mu \mathrm{g} / \mathrm{dL}) \\
\quad(n)\end{array}$ & $\begin{array}{c}291.1 \pm 246.8 \\
(346)\end{array}$ & $\begin{array}{c}360.3 \pm 292.6 \\
(401)\end{array}$ & $\begin{array}{c}487.8 \pm 369.2 \\
(416)\end{array}$ & $<0.001$ \\
\hline$\underset{(n)}{\operatorname{Vitamin}} \mathrm{B}_{12}(\mathrm{pg} / \mathrm{mL})$ & $\begin{array}{c}445.7 \pm 257.8 \\
(311)\end{array}$ & $\begin{array}{c}465.7 \pm 264.7 \\
(343)\end{array}$ & $\begin{array}{c}502.0 \pm 326.6 \\
(367)\end{array}$ & $<0.05$ \\
\hline $\begin{array}{l}\text { Folate }(\mathrm{ng} / \mathrm{mL}) \\
\quad(n)\end{array}$ & $\begin{array}{l}5.9 \pm 4.2 \\
(318)\end{array}$ & $\begin{array}{c}6.8 \pm 6.5 \\
(401)\end{array}$ & $\begin{array}{c}8.1 \pm 7.2 \\
(406)\end{array}$ & $<0.01$ \\
\hline $\begin{array}{l}\text { Vitamin } \mathrm{B}_{2} / \mathrm{Cr}(\mu \mathrm{g} / \mathrm{g}) \\
\quad(n)\end{array}$ & $\begin{array}{c}126.8 \pm 153.78 \\
(281)\end{array}$ & $\begin{array}{c}161.3 \pm 163.8 \\
(334)\end{array}$ & $\begin{array}{c}182.5 \pm 215.4 \\
(402)\end{array}$ & $>0.05$ \\
\hline
\end{tabular}

${ }^{a}$ Means \pm SD. ${ }^{b}$ Number of subjects tested. ${ }^{c} p$ values are the comparisons between the five groups of $\mathrm{Hb} \leq 100 \mathrm{~g} / \mathrm{L}$ and $\geq 120 \mathrm{~g} / \mathrm{L}$ by analysis of variance. 
$\leq 100 \mathrm{~g} / \mathrm{L}$ and $\mathrm{Hb} \geq 120 \mathrm{~g} / \mathrm{L}$ as shown in Table 1 . There was a lower level of serum retinol in the $\mathrm{Hb} \leq 100 \mathrm{~g} / \mathrm{L}$ group than the $\mathrm{Hb} \geq 120 \mathrm{~g} / \mathrm{L}$ group $(p<0.001)$. The serum ascorbic acid was lower in the $\mathrm{Hb} \leq 100 \mathrm{~g} / \mathrm{L}$ group $(291.05 \mu \mathrm{g} / \mathrm{dL})$ than in the $\mathrm{Hb} \geq 120 \mathrm{~g} / \mathrm{L}$ group $(487.79 \mu \mathrm{g} / \mathrm{dL})(p<0.001)$. Serum levels of vitamin $\mathrm{B}_{12}$ and folate were $445.67 \mathrm{pg} / \mathrm{mL}$ and $5.94 \mathrm{ng} / \mathrm{mL}$ respectively in the $\mathrm{Hb} \leq 100 \mathrm{~g} / \mathrm{L}$ group, which were much lower than the levels of $502.01 \mathrm{pg} / \mathrm{mL}$ and $8.07 \mathrm{ng} / \mathrm{mL}$ in the $\mathrm{Hb} \geq 120 \mathrm{~g} / \mathrm{L}$ group $(p<0.012, p<0.01)$. However, there was no significant difference of vitamin $\mathrm{B}_{2} /$ $\mathrm{Cr}$ in urine between the $\mathrm{Hb} \leq 100 \mathrm{~g} / \mathrm{L}$ group and the $\geq 120 \mathrm{~g} / \mathrm{L}$ group $(p>0.05)$.

Abnormal hematological values associated with the prevalence of vitamin deficiencies were shown in Table 2. There were $41.58 \%$ of the subjects with serum iron $<700 \mu \mathrm{g} / \mathrm{L}$ in the anemic $(\mathrm{Hb}<110 \mathrm{~g} / \mathrm{L})$ group, which was higher than that in the nonanemic group $(\mathrm{Hb} \geq 110 \mathrm{~g} / \mathrm{L})$. The rate of iron depletion in the pregnant women was also much higher in the anemic group than the nonanemia group. The higher deficiencies of serum vitamin $C$, folate and vitamin $B_{12}$ were found in the anemic group than those in the nonanemia group, and especially the deficient rates of ascorbic acid and folate in the anemia population reached to $64.04 \%$ and $22.70 \%$, respectively.

Changeable trends of serum levels of five vitamins associated with hemoglobin concentrations were shown in Fig. 1. The curve of serum vitamin $C$ in Fig. 1(a) was gradually rising accompanied by increasing hemoglobin concentration. The serum levels of retinol, vitamin $\mathrm{B}_{12}$, folate and riboflavin/Cr increased along with increasing hemoglobin concentration from $70 \mathrm{~g} / \mathrm{L}$ to $150 \mathrm{~g} / \mathrm{L}$ as shown in Fig. 1(b), (c), (d), (e), respectively.

\section{DISCUSSION}

Anemia is a public health problem and its common type is iron-deficiency anemia both in Chinese pregnant and nonpregnant women. It was reported that there were $28.25 \%$ and $25.82 \%$ of nonpregnant women in cities and rural areas respectively (16), while a prevalence of anemia in pregnant women is even more severe. There was a higher incidence of anemia in preg- nant women and $44.3 \%$ subjects tested with iron-deficient anemia in this study. The reasons for the prevalence of anemia in pregnant women are not only related to a greater requirement of iron due to an expanded red blood cell volume, the needs of the fetus and placenta and blood loss at delivery (17), but also poor iron intake or low bioavailability $(<10 \%)$ from a traditional Chinese diet (65-80\% vegetables) (18). The bioavailability of nonheme iron was considered to be dependent on the interaction of the promoters and the inhibitors of iron absorption from diets $(19,20)$. The two most common inhibitors of nonheme iron absorption are polyphenoles and phytates, whose presence in foods such as cereals and legumes have shown a marked decrease in the bioavailability of dietary iron. Iron absorption decreased progressively when the intake of phytate phosphorous (from 10 to $58 \mathrm{mg}$ ) from maize bran was increased. However, the inhibitory effect was overcome by $30 \mathrm{mg}$ of ascorbic acid, and so it was suggested that more than $50 \mathrm{mg}$ of ascorbic acid would be required to overcome the inhibitory effects on iron absorption of any meal containing $>100 \mathrm{mg}$ tannic acid (21). In our study, low levels of serum vitamin $\mathrm{C}$ occurred both in the anemia and nonanemia populations, and vitamin $\mathrm{C}$ marginal deficiency was more severe in pregnant women with anemia than nonanemia. During pregnancy, serum vitamin $\mathrm{C}$ progressively decreased by $50 \%$, partly because of the extra consumption by the fetus and partly because of hemodilution (22). Moreover, our investigation was carried out during the winter from September to April in order to limit the subjects' intake of green vegetables and ascorbic acid. In addition, the standard Chinese diet contains a lot of the inhibitors of iron absorption and is commonly stir-fried, and fresh fruits are seldom eaten with a meal (18). As the enhancing effect of ascorbic acid on the absorption of nonheme iron is well known (23), iron supplementation with ascorbic acid is expected to be more effective (24).

Vitamin A deficiency occurs when the intake of dairy products and carotene-rich vegetables and fruit is limited. The prevalence of vitamin A deficiency in this study was very high and about $14 \%$ of pregnant women had a serum retinol concentration of $<20 \mu \mathrm{g} /$

Table 2. Abnormal hematological values and prevalence of marginal deficiencies of vitamins in pregnant Chinese women in the last trimester.

\begin{tabular}{|c|c|c|c|c|c|c|c|c|}
\hline \multirow{2}{*}{ Indices } & \multirow{2}{*}{$\begin{array}{l}\text { Abnormal range } \\
\text { of index values }\end{array}$} & \multicolumn{2}{|c|}{$\mathrm{Hb}<110 \mathrm{~g} / \mathrm{L}$} & \multicolumn{2}{|c|}{$\mathrm{Hb} \geq 110 \mathrm{~g} / \mathrm{L}$} & \multicolumn{2}{|c|}{ Total } & \multirow{2}{*}{$p^{\mathrm{b}}$} \\
\hline & & $(n)^{\mathrm{a}}$ & $\%$ & $(n)$ & $\%$ & $(n)$ & $\%$ & \\
\hline Serum iron & $<700 \mu \mathrm{g} / \mathrm{L}$ & $(505)$ & 41.58 & $(515)$ & 30.49 & $(1,020)$ & 35.98 & $<0.001$ \\
\hline Ferritin & $<12 \mu \mathrm{g} / \mathrm{L}$ & (531) & 51.04 & $(584)$ & 38.18 & $(1,115)$ & 44.30 & $<0.001$ \\
\hline Vitamin C & $<400 \mu \mathrm{g} / \mathrm{dL}$ & $(570)$ & 64.04 & (593) & 56.49 & $(1,163)$ & 36.89 & $<0.010$ \\
\hline Retinol & $<20 \mu \mathrm{g} / \mathrm{dL}$ & $(545)$ & 13.76 & $(555)$ & 3.06 & $(1,100)$ & 8.36 & $<0.001$ \\
\hline Vitamin $B_{12}$ & $<200 \mathrm{pg} / \mathrm{mL}$ & $(507)$ & 12.62 & $(512)$ & 8.40 & $(1,019)$ & 10.50 & $<0.030$ \\
\hline Folate & $<3.0 \mathrm{ng} / \mathrm{mL}$ & (551) & 22.70 & $(573)$ & 16.90 & $(1,124)$ & 19.80 & $<0.003$ \\
\hline
\end{tabular}

${ }^{\mathrm{a}} \mathrm{n}$ values in parentheses are number of subjects. ${ }^{b} p$ values are comparisons between the anemic group $(\mathrm{Hb}<110 \mathrm{~g} / \mathrm{L})$ and nonanemic group $(\mathrm{Hb} \geq 110 \mathrm{~g} / \mathrm{L})$. 

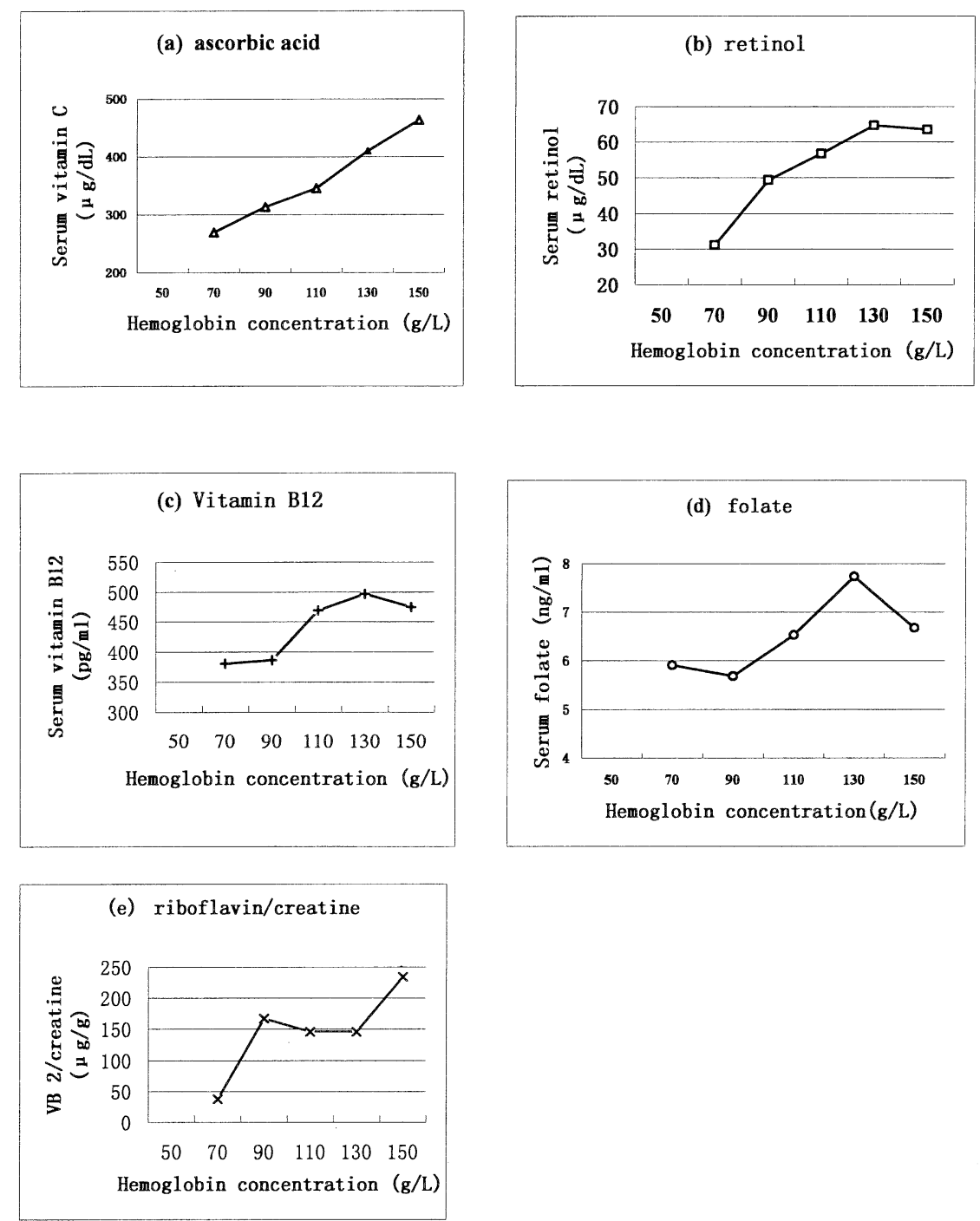

Fig. 1. Relationships between indicators of vitamin status and iron status in Chinese pregnant women in the last trimester. The figures of (a)-(e) show distribution of mean levels of five serum vitamins to hemoglobin concentrations in all subjects tested.

dL in the anemic group, which might be related with low intakes of vitamin $A$ and insufficient $\beta$-carotene in their diet (18). The effect of vitamin A deficiency on iron status has found an association between serum retinol and hemoglobin concentrations in pregnant women (25), suggesting that vitamin A deficiency decreases hemoglobin syntheses (26). An increase of $4 \mathrm{~g} /$ $\mathrm{L}$ to $10 \mathrm{~g} / \mathrm{L}$ in hemoglobin was associated with a 1 $\mu \mathrm{mol} / \mathrm{L}$ increase in serum retinol concentration (27), and vitamin $A$ and $\beta$-carotene can also improve nonheme iron absorption from rice, wheat and corn in humans (28). Vitamin A binds iron liberated during the digestive process and forms a complex that acts as a chelating agent preventing the inhibitory effect of phytate and polyphenols on nonheme iron absorption (29). Moreover, the mechanism of significant interaction between serum retinol and hemoglobin or anemia is unclear. Vitamin A may inhibit erythropoiesis directly (30) or through inhibition of iron mobilization or transport (31).

The rate of folate deficiency was found to be about
$22.7 \%$ in the anemic pregnant women compared to $16.9 \%$ in the nonanemic pregnant women, and was accompanied by other vitamin deficiencies in this study (Table 2). The reason may be primarily a result of dietary folate insufficiency. Folate supplementation to iron was able to decrease iron deficiency anemia in pregnancy (32). Routine folate, iron and folate and iron supplementation results in a substantial reduction of women with hemoglobin levels $<100 \mathrm{~g} / \mathrm{L}$ in late pregnancy (33-35). In the case of pregnant women, a daily dose of one tablet containing $60 \mathrm{mg}$ iron and $400 \mu \mathrm{g}$ folic acid has been recommended for all except those who are severely anemic (36).

Although vitamin $\mathrm{B}_{12}$ deficiency was very uncommon (37), serum vitamin $B_{12}$ concentration of pregnant women with anemia was much lower than that in the nonanemia population in this study. The independent effect of vitamin $\mathrm{B}_{12}$ deficiency had been examined on hematological indices in older Chinese vegetarian women using a cross-sectional study design. Vitamin $B_{12}$ deficiency defined by serum vitamin $B_{12}$ and meth- 
ylmalonic acid (MMA) was associated with a decrease in hemoglobin concentrations by up to $0.9 \mathrm{~g} / \mathrm{dL}$, but it was not associated with an increase in mean corpuscular volume $(\mathrm{MCV})$. Serum MMA but not vitamin $\mathrm{B}_{12}$ levels correlated inversely with hemoglobin and platelet counts and positively with MCV, after adjustment of confounding factors. So anemia associated with vitamin $B_{12}$ deficiency was seldom macrocytic (38).

While iron deficiency is regarded as the major cause of nutritional anemia, changes in vitamins $\mathrm{A}, \mathrm{B}_{12}, \mathrm{C}$ and $\mathrm{E}$, folic acid and riboflavin status have also been linked to its development and control. Our study showed that iron status was related to levels of vitamins in serum, which suggested that vitamin $C$, retinol or carotene, folate, vitamin $\mathrm{B}_{12}$ might be main causes to promote iron absorption and decrease the rate of anemia in pregnant women in the last trimester. The anemic pregnant women should increase their daily intake of heme food or take multiple vitamins and iron supplementation. Multiple vitamin supplements may raise hemoglobin $(\mathrm{Hb})$ concentration, but few studies have isolated the effect of multiple vitamins from iron on hematological status. Further research is needed to understand the roles of individual and combined vitamin deficiencies on anemia to design appropriate micronutrient interventions to prevent anemia (39).

\section{Acknowledgments}

We sincerely acknowledge Dr Evert Schouten, Dr Joseph Hautvast and Dr Beat Schürch for their help. The authors also thank Zhang Xiuzhen, Liang Hui, Du Wei, Xu Hongwei, Zhang Shehua, Wang Xiuli, Liu Ying, Sun Yongli, Xu Peilong and Shi Xuexiang for measuring ferritin and technical assistance in vitamin $A$, ascorbic acid, vitamin $B_{12}$, folate in serum and vitamin $B_{2}$ in urine analyses; Wang Xin and Li Yong for managing the contacts with subjects; Han Xiuxia and Song Xuxia for data statistics.

\section{REFERENCES}

1) Galloway R, Dusch E, Elder L, Achadi E, Grajeda R, Hurtado E, Favin M, Kanani S, Marsaban J, Meda N, Moore KM, Morison L, Raina N, Rajaratnam J, Rodriquez J, Stephen C. 2002. Women's perceptions of iron deficiency and anemia prevention and control in eight developing countries. Soc Sci Med 55: 529-544.

2) Jin H, Han Q, Liang CA, Li L, Wu YZ, Zhao Q. 1995. The epidemiological study of iron-deficiency in pregnant women. Xi'an Yi Ke Da Xue Xue Bao 16: 437-439 (in Chinese).

3) Liu LJ, Lai YH, Hu ZH, Ji W, Wu YJ, Liu CQ. 1998. Investigation of anemia of 158 pregnant women in Jilin's city. Ji Lin Yi Xue Yuan Xue Bao 18: 45-47 (in Chinese).

4) Ladipo OA. 2000. Nutrition in pregnancy: mineral and vitamin supplements. Am J Clin Nutr 72(Suppl): 280s290s.

5) Zhang YA, Shao TX, Ding Y, Zhao L, Ye LP, Zhang HZ, Huang Y. 1999. The relationship between anemia and vitamin A of pregnant women in a rural area. J LuoYang Med Sch 17: 172-174 (in Chinese).

6) Shu J, Li X, Jin H, Zhang J, Li L. 1995. Investigation of nutritional status of pregnant women in rural areas. $J$
Chin Basic Health Care 9: 39-40 (in Chinese).

7) Bloem MW, Wedel M, van Agtemaal EJ, Speck AJ, Saowakontha S, Schreurs WHP. 1990. Vitamin A intervention: short-term effects of a single, oral, mass dose on iron metabolism. Am J Clin Nutr 51: 76-79.

8) Xu GF, Wu J, Wang SQ, Wang HW. 1997. Investigation of anemia and nutritional status in the second and third trimester of pregnancy. Acta Nutr Sinica 19: 316-320 (in Chinese).

9) Tang Y, Zhou RH. 1999. Relationship between vitamin $\mathrm{B}_{2}$ and iron deficient anemia during pregnancy. Acta Nutr Sinica 21: 462-465 (in Chinese).

10) Chu SL, Chen YZ, Xue JZ, Ni QG, Wang YL. 1983. Measurement of clinical application of ferritin by radioimmunoassay. Chin J Hematol 4: 296-298.

11) Futterman S, Swansan D, Kalina RE. 1975. A new, rapid fluorometric determination of retinol in serum. Invest Ophthalmol 14: 125-130.

12) Rose JH, Kuether CH. 1943. The determination of ascorbic acid in whole blood and urine through the 2,4-dinitrophenylhydrazine derivative of dehydroascorbic acid. $J$ Biol Chem 147: 399-407.

13) Margolis SA, Duewer DL. 1996. Measurement of ascorbic acid in human plasma and serum: stability, intralaboratory repeatability, and interlaboratory reproducibility. Clin Chem 42: 1257-1262.

14) Chinese Nutritional Society. 2000. Chinese Dietary Reference Intakes, The first edition, vol. 10, p 261-350. Chinese Light Industry Publication House, Beijing.

15) Magnus EM. 1982. Folate and vitamin $B_{12}$ (cobolamin) blood levels in elderly persons in geriatric homes. Scand J Haematol 28: 99-106.

16) Chang SY, Ge KY, Zhai FY, Jia FM, Xu QM. 1998. The analysis nutritional factors on anemia in Chinese adults. Acta Nutr Sinica 20: 132-137 (in Chinese).

17) Letsky EA. 1995. Erythropoiesis in pregnancy. J Perinat Med 23: 39-45.

18) Ma AG, Chen XC, Zheng MC, Wang Y, Xu RX, Li JS. 2002. Iron status and dietary intake of Chinese pregnant women with anemia in the third trimester. Asia Pacific J Clin Nutr 11: 171-175.

19) Gillooly M, Bothwell TH, Torrance JD, MacPhail AP, Derman DP, Bezwoda WR, Mills W, Charlton RW, Mayet F. 1983. The effects of organic acids, phytates and polyphenoles on the absorption of iron from vegetables. Br J Nutr 49: 331-342.

20) Macfarlane BJ, Bezwoda WR, Bothwell TH, Baynes RD, Bothwell JE, MacPhail AP, Lamparelli RD, Mayet F. 1988. Inhibitory effect of nuts on iron absorption. Am J Clin Nutr 47: 270-274.

21) Siegenberg D, Baynes RD, Bothwell TH, Macfarlane BJ, Lamparelli RD, Car NG, MacPhail P, Schmidt U, Tal A, Mayet F. 1991. Ascorbic acid prevents the dose-dependent inhibitory effects of polyphenols and phytates on nonheme-iron absorption. Am J Clin Nutr 53: 537-541.

22) Drife J, MacNab G. 1986. Mineral and vitamin supplements. Clin Obstet Gynaecol 48: 595-600.

23) Hallberg L, Brune M, Rossander L. 1986. Effect of ascorbic acid on iron absorption from different types of meals. Hum Nutr Appl Nutr 40A: 97-113.

24) Lynch SR, Dassenko SA, Morck TA, Beard JL, Cook JD. 1985. Soy protein products and heme iron absorption in humans. Am J Clin Nutr 41: 13-20.

25) Bondevik GT, Eskeland B, Ulvik RJ, Ulstein M, Lie RT, Schneede J, Kvale G. 2000. Anemia in pregnancy: possi- 
ble causes and risk factors in Nepali women. Eur J Clin Nutr 54: 3-8.

26) Christian P, West KP Jr, Khatry SK, Katz J, Shrestha SR, Pradhan EK, LeClerq SC, Pohkrel RP. 1998. Night blindness of pregnancy in rural Nepal; nutritional and health risks. Int J Epidemiol 27: 231-237.

27) Ahmed F, Khan MR, Karim R, Taj S, Hyderi T, Faruque MO, Margetts BM, Jackson AA. 1996. Serum retinal and biochemical measures of iron status in adolescent schoolgirls in urban Bangladesh. Eur J Clin Nutr 50: 346-351.

28) Garcia-Casal MN, Layrisse M, Solano L, Baron MA, Arguello F, Llovera D, Ramirez J, Leets I, Tropper E. 1998. Vitamin $A$ and $\beta$-carotene can improve nonheme iron absorption from rice, wheat and corn by humans. J Nutr 128: 646-650.

29) Layrisse M, Garcia-Casal MN, Solano L, Baron MA, Arguello F, Llovera D, Ramirez J, Leets I, Tropper E. 2000. New property of vitamin A and beta-carotene on human iron absorption: effect on phytate and polyphenols as inhibitors of iron absorption. Arch Latinoam Nutr 50: $243-248$.

30) West KP Jr, Katz J, Khatry SK, LeClerq SC, Pradhan EK, Shrestha SR, Connor PB, Dali SM, Christian P, Pokhrel R, Sommer A. 1999. Double blind, cluster randomized trial of low dose supplementation with vitamin A or beta-carotene on mortality related to pregnancy in Nepal. Br Med J 318: 570-575.

31) Wolde- Gebriel Z, West CE, Haile Gebru Tadesse AS, Fisseha T, Gabre P, Ayana G, Hautvast JGAJ. 1993. Interrelationship between vitamin $\mathrm{A}$, iodine and iron status in school children in Shoa Region, Central Ethiopia. $\mathrm{Br} J$
Nutr 70: 593-607.

32) Juarez-Vazquez J, Bonizzoni E, Scotti A. 2002. Iron plus folate is more effective than iron alone in the treatment of iron deficiency anemia in pregnancy: a randomized, double blind clinical trial. BJOG 109: 1009-1014.

33) Mardones-Santander F, Salazar G, Rosso P, Villarroel L. 1998. Maternal body composition near term and birth weight. Obstet Gynecol 91: 873-877.

34) Villar J, Rivera J. 1988. Nutritional supplementation during two consecutive pregnancies and the interim lactation period: effect on birth weight. Pediatrics $\mathbf{8 1}$ : $51-57$.

35) Villa J, Mackey ME, Carroli G, Donner A. 2001. Metaanalysis in systematic reviews of randomized controlled trial in perinatal medicine: comparison of fixed and random effects models. Stat Med 20: 3635-3647.

36) Keen CL, Zidenberg-Cherr S. 1994. Should vitaminmineral supplements be recommended for all women with childbearing potential? Am J Clin Nutr 59 (Suppl): 532S-538S; discussion 538S-539S.

37) Lamparelli RD, Bothwell TH, MacPhail AP, van der Westhuyzen J, Baynes RD, MacFarlane BJ. 1988. Nutritional anaemia in pregnant coloured women in Johannesburg. S Afr Med J 73: 477-481.

38) Kwok T, Cheng G, Woo J, Lai WK, Pang CP. 2002. Independent effect of vitamin $\mathrm{B}_{12}$ deficiency on hematological status in older Chinese vegetarian women. Am J Hematol 70: 186-190.

39) Fishman SM, Christian P, West KP. 2000. The role of vitamins in the prevention and control of anaemia. Public Health Nutr 3: 125-150. 